\title{
Historycznie stosowane impregnaty do wzmacniania zniszczonego drewna polichromowanego - próba przeglądu. Część I: Impregnaty naturalne
}

\section{Zagadnienia wstępne}

T mpregnacja wzmacniająca jest jednym z istotnych, często podejmowa1 nych w praktyce konserwatorskiej działań przy obiekcie zabytkowym.

Jej założeniem jest głębokie przesycenie całej struktury materiału, prowadzacce do jego dostatecznego wzmocnienia, ustabilizowania i ochrony. W przypadku drewna jest to szczególnie istotne, gdyż niektóre objawy zniszczenia, zwłaszcza spowodowane przez czynniki biologiczne, występuja w jego głębokich warstwach. Uzyskany efekt jest uzależniony od wielu czynników, przede wszystkim od zastosowania odpowiednich środków i metod przesycania oraz stworzenia możliwości trwałego związania impregnatu w strukturze drewna podczas zachodzacych zjawisk fizycznych, reakcji chemicznych lub obu tych procesów jednocześnie. Kształtują go także gatunek i właściwości drewna, jego budowa anatomiczna - ilościowy udział bielu i twardzieli, gęstość, porowatość, stopień zniszczenia, wilgotność oraz technika i technologia wykonania warstw złoceń i polichromii w przypadku technologicznie złożonych obiektów zabytkowych ${ }^{1}$.

1 Adhesives and Coatings, Conservation Science Teaching Series, Science for Conservators, vol. 3, Frome and London 1994, s. 124; U. Bieszczad, Wymiana zniszcronego drewna 
Najważniejsze jednak dla uzyskania pożądanego efektu głębokiego przesycenia struktury drewna impregnatem są użyte środki i metody ich wprowadzania.

Ich dobór jest szczególnie istotny ze względu na wskazywany przez wielu fakt nieodwracalności zabiegu impregnacji, pomimo odwracalności

rzę́by polichromowanej na pianke poliuretanowa. Praca magisterska pod kierunkiem dr Bożeny Soldenhoff, wykonana w Zakładzie Konserwacji Malarstwa i Rzeźby Polichromowanej Instytutu Zabytkoznawstwa i Konserwatorstwa, Toruń 1982, s. 9 [mps przechowywany w bibliotece ZKMiRP, nr 102]; W. Domasłowski, Konserwacja (wrmacnianie, utwardzanie) drewna pod zmniejszonym ciśnieniem, Zagadnienia Konserwacji Drewna, Biblioteka Muzealnictwa i Ochrony Zabytków, seria B, t. 3, 1961, s. 47; idem, Zagadnienie konserwacji drewna, „Materiały Zachodnio-Pomorskie", t. 4, 1958, s. 407; R. Kawczyński, Nasycanie drewna środkami chemicznymi, Warszawa 1972, s. 106-107; W. Kokociński, Drewno. Pomiary wtaściwości fiasycznych i mechanicznych, Poznań 2004, s. 38, 48; P. Kotlik, Impregnation under low pressure, „Studies in Conservation", nr 1, 1998, s. 42; M. Makowska, Problemy konserwacji i restauracji rzę́by drewnianej polichromowanej na praykktadzie krucyfiksu z Izbicy Kujawskiej. Praca magisterska napisana w Zakładzie Konserwacji Malarstwa i Rzeźby Polichromowanej Instytutu Zabytkoznawstwa i Konserwatorstwa UMK w Toruniu pod kierunkiem doc. dr hab. Marii Roznerskiej, Toruń 1985, s. 38, 41 [mps przechowywany w bibliotece ZKMiRP, nr 116]; M. Malarska, Metody konserwacij podobrazi drewnianych na podstawie literatury oraz realizacij konserwatorskich $w$ Zaktadžie Konserwacji Malarstwa $i$ Ržeźby Polichromowanej. Praca magisterska napisana w Zakładzie Konserwacji Malarstwa i Rzeźby Polichromowanej pod kierunkiem dr Bożeny Soldenhoff, Uniwersytet Mikołaja Kopernika, Wydział Sztuk Pięknych, Toruń 2000, s. 57-58 [mps przechowywany w bibliotece ZKMiRP, nr 207]; M. Mietlicka, Badania nad efektywnościa zabiegón impregnacji wzmacniajacej podobrazi drewnianych. Praca magisterska została napisana w Zakładzie Konserwacji Malarstwa i Rzeźby Polichromowanej Uniwersytetu Mikołaja Kopernika w Toruniu pod kierunkiem dr Bożeny Soldenhoff, Toruń 1998, s. 58 [mps przechowywany w bibliotece ZKMiRP, nr 203]; M. Paciorek, Badania wybranych tworzyw termoplastycznych stosowanych do impregnacji drewna, Studia i Materiały Wydziału Konserwacji i Restauracji Dzieł Sztuki Akademii Sztuk Pięknych w Krakowie, t. 3, Kraków 1993, s. 7-9, 62; idem, Metody impregnacji drewna, „Renowacje”, nr 2, 1998, s. 24-25; idem, Zastosowanie tomografii komputerowej do badania rozmieszczenia i udziatu tworzywa w drewnie impregnowanym strukturalnie, Czterdziestolecie Wydziału Konserwacji Dzieł Sztuki Akademii Sztuk Pięknych w Krakowie (1950-1990), Biblioteka Muzealnictwa i Ochrony Zabytków, ser. B, t. 88, 1992, s. 212; idem, Zastosowanie tomografii komputerowej do badania rozmieszczenia $i$ udziatu tworyywa w drewnie impregnowanym strukturalnie, „Ochrona Zabytków”, nr 3, 1992, s. 159; E. Šimůnková, Z. Šmejkalova, Consolidation of wood by method of monomer polymerization in the object, "Studies in Conservation", nr 3, 1983, s. 135; W. Ślesiński, Konserwacja zabytkón squtuki, t. 1: Malarstwo sz̨alugowe i ścienne, Warszawa 1989, s. 22; idem, Konserwacja zabytkón sztuki, t. 3: Rzemiosto artystyczne, Warszawa 1995 , s. 22 
stosowanych środków². Trafnie zagadnienie to ujmował już w 1966 roku W. Kurpik, który pisał: „,należy stwierdzić, że odwracalność wprowadzonego impregnatu daje tylko dość iluzoryczne podstawy do przypuszczenia, że uda się ten impregnat kiedykolwiek z powrotem usunąć, zachowując przy tym istniejacy stan drewna"3. C. V. Horie stwierdza zaś zdecydowanie: „Trzeba pamiętać, że obiekt osłabiony na tyle, aby wymagać konsolidacji, jest zbyt słaby, aby wytrzymać próby wyprowadzenia konsolidanta"^. Trudno się z tymi opiniami nie zgodzić.

Stosowane materiały zmieniały się i zmieniają wraz z postępująca na ten temat wiedzą. Kolejne pokolenia konserwatorów wykorzystują środki uznawane w danym czasie za najlepsze lub też będące w powszechnym użyciu. Czas te oceny weryfikuje.

Generalnie, stosowane impregnaty wzmacniające można podzielić na oparte na materiałach naturalnych i syntetycznych.

Do pierwszej grupy zwyczajowo zalicza się: wodę klejową, oleje schnące - głównie olej lniany, roztwory żywic naturalnych (kalafonii, damary, mastyksu i szelaku) oraz masy woskowo-żywiczne. Środki te, kiedyś popularne, obecnie stosowane są coraz rzadziej, wręcz sporadycznie, jednak spotkać je można w wielu obiektach konserwowanych w przeszłości.

2 R. L. Barclay, Wood consolidation on an eighteenth century English fire engine, "Studies in Conservation", nr 4, 1981, s. 137-138; C. V. Horie, Materials for Conservation, Butterworths-London-Boston-Durban-Singapore-Sydney-Toronto-Wellington 1978, s. 78; W. Kurpik, Utwardzanie zniszczonego drewna pray pomocy symic syntetycznych. Wykonywanie plomb trocinowo-symicznych, „Materiały Muzeum Budownictwa Ludowego w Sanoku”, nr 3, 1966, s. 28; M. Makowska, op. cit., s. 34; D. E. Olczak, Metody i środki konserwacji polichromowanych ræęźb drewnianych oraz ich zastosowanie w Zakładzie Konserwacij Malarstwa $i$ Rzę́by Polichromowanej UMK w Toruniu. Praca magisterska napisana w Zakładzie Konserwacji Malarstwa i Rzeźby Polichromowanej Instytutu Zabytkoznawstwa i Konserwatorstwa UMK w Toruniu pod kierunkiem doc. dr hab. Marii Roznerskiej, Toruń 1985, s. 49 [mps przechowywany w bibliotece ZKMiRP, nr 115]; U. Schiessl, Probleme der Konservierungsstoffe zur Festigkeiterhöbung von degradiertem Holv, [w:] M. Bilfinger, D. Meili (Herausgeber), Konservierung von Holz̧auten, Bern-Stuttgart 1989, s. 105; K. Sibul, Materials Used in Conservation of Painted Wooden Objects in Estonia, Materiały z konferencji ARIADNE NR 10, Praga 22-28.04.2002, s. 3.

3 W. Kurpik, op. cit., s. 28.

4 C. V. Horie, op. cit., s. 78 (cytuje w tłumaczeniu własnym). 


\section{Wodne roztwory klejów glutynowych}

Wodne roztwory klejów glutynowych oparte są na klejach skórnych, kostnych i rybich ${ }^{5}$. W. Ślesiński zauważa, że impregnacja wodą klejową, dzisiaj już zaniechana, ma ponad dwustuletnią tradycje $e^{6}$. R. Munnikendam podaje, że została ona rozwinięta na początku ubiegłego stulecia ${ }^{7}$. Zdaniem B. Slánskiego została przejęta od rzeźbiarzy i pozłotników, którzy rzeźby o drewnie zniszczonym przez owady zanurzali w wodzie klejowej, co miało służyć nie tylko impregnacji drewna, lecz również podklejeniu polichromii ${ }^{8}$. Również U. Bieszczad pisze, że zanurzanie rzeźb w wodzie klejowej było częstym zabiegiem. Autorka zauważa jednocześnie, że w przypadku rzeźb polichromowanych do efektu pęcznienia drewna i zaprawy dołączał się skurcz kleju po wyschnięciu, mogący doprowadzić do zapadania się fragmentów polichromii ${ }^{9}$. Ponadto mogło to powodować pogłębiające się w miarę upływu czasu przyciemnienie warstwy malarskiej ${ }^{10}$. J. Krawczyk

5 Podstawowym składnikiem klejów glutynowych są białka proste, otrzymywane przez hydrolizę kolagenu. Źródłem kolagenu są odpady skór, chrząstki, kopyta i tym podobne. Kolagen przez hydrolizę przechodzi w rozpuszczalną w gorącej wodzie glutynę. Czastki glutyny mają strukturę liniową. W zimnej wodzie glutyna silnie pęcznieje, z roztworu oziębionego koaguluje, natomiast po odparowaniu wody tworzy twardą masę o różnej barwie - od bezbarwnej do czarnej, o wyraźnym zapachu. Poszczególne gatunki glutyny różnią się od siebie jedynie stopniem czystości i wyglądem. Swoisty jest skład aminokwasów występujących w klejach glutynowych, jako jedyne białko zawierają one aminokwas hydroksyprolinę, około $14,5 \%$, ponadto dużo glicyny, około $26,9 \%$, i proliny - 14,80\% oraz mniejsze ilości innych aminokwasów. Niemodyfikowane kleje glutynowe są termoplastyczne. Pod wpływem podwyższonej temperatury $\left(\right.$ do $60^{\circ} \mathrm{C}$, gdyż przy tej temperaturze następuje denaturacja cząsteczek glutyny) lub wody przechodzą w stan ciekły. Ich odporność na oddziaływanie wody jest bardzo mała. Za: H. Krach, Chemia stosowana w drzewnictwie, Warszawa 1973, s. 200; E. Mirowska, M. Poksińska, B. Rouba, I. Wiśniewska, Identyfikacja podobrazi i spoin malarskich w rabytkonych dziełach sætuki, Toruń 1992, s. 199.

6 W. Ślesiński, Konserwacja zabytkón squtuki, t. 1, s. 23; idem, Konserwacja zabytkón squtuki, t. 2: Rz̨eźba, Warszawa 1990, s. 20.

7 R. Munnikendam, Consolidation of fragile wood with low viscosity aliphatic epoxy resins, [w:] Conservation of wood in Painting and the Decorative Arts, Preprints of the Contributions to the Oxford Congress, 17-23 September 1978, London 1978, s. 71.

8 B. Slánský, Technika malarstwa, t. 2: Badanie i konserwowanie obrazón, Warszawa 1965, s. 183.

9 U. Bieszczad, op. cit., s. 9.

10 M. Wierucka, Badanie polialkoholi winylowych do utrwalania tuszczacych sie malowidet ściennych na podto:iu drewnianym. Praca magisterska wykonana w Zakładzie Konserwacji Malarstwa 
wskazuje, że był to środek tradycyjnie stosowany do wzmacniania elementów drewnianych mebli ${ }^{11}$. E. De Witte z kolei wymienia klej rybi wśród impregnatów naturalnych stosowanych do lat 30. XX wieku ${ }^{12}$. Jedynie I. Swaczyna jeszcze w latach 90. ubiegłego stulecia zaliczała wodę klejowa do ,środków wzmacniających spełniających wymagania stawiane tego typu preparatom" i polecała roztwór kleju o niskiej lepkości z dodatkiem soku czosnkowego lub z cebuli ${ }^{13}$. Wzmianki o stosowaniu w Polsce do tego celu klejów glutynowych pochodzą z lat 60 . XX wieku. Wymieniany jest sam $\mathrm{klej}^{14}, \mathrm{z}$ dodatkiem pokostu ${ }^{15}$, stosowany wymiennie w jednym obiekcie z roztworem Vinoflexu ${ }^{16}$, jako alternatywa dla wosku ${ }^{17}, \mathrm{z}$ dodatkiem forma-

i Rzeźby Polichromowanej. Promotor prof. dr Bogumiła Rouba, prof. dr Maria Roznerska przy współpracy dr Ewy Roznerskiej-Świerczewskiej, Uniwersytet Mikołaja Kopernika, Toruń 2002, s. 29 [mps przechowywany w bibliotece ZKMiRP, nr 227].

11 J. Krawczyk, Badania nankowe w analizie $i$ konserwacji mebli zabytkowych, „Ochrona Zabytków", nr 1-2, 1992, s. 39.

12 E. De Witte, Resins in conservation: introduction to their properties and application, [w:] The proceedings of the symposium Resins in conservation held at the University of Edinburgh $21^{\text {st }}-22^{\text {nd }}$ May 1982, Edinburgh 1988, s. 1-1.

13 I. Swaczyna, Meble - naprawa i odnawianie, Warszawa 1995, s. 66.

14 Spis dokumentaci konserwatorskich zabytków ruchomych, cz. 1: dla zabytków znajdujących się poza muzeami, O-Ż, Biblioteka Muzealnictwa i Ochrony Zabytków, ser. B, t. 39, 1975, s. 17.

15 Ibidem, s. 141; Spis dokumentacii konserwatorskich qabytków ruchomych, cz. 1: dla zabytków znajdujących się poza muzeami, A-N, Biblioteka Muzealnictwa i Ochrony Zabytków, ser. B, t. 39, 1975, s. 278 .

${ }_{16}$ Spis dokumentacji konserwatorskich zabytków ruchomych, cz. 1: dla zabytków znajdujących się poza muzeami, O-Ż, s. 35.

Vinoflex MP-400 był jednym z popularniejszych impregnatów do drewna spośród kopolimerów pochodnych winylowych. Pod względem chemicznym żywica ta była kopolimerem chlorku winylu i eteru winylowoizobutylowego. Podaję za: B. Chaber, Badania nad impregnacja desek podobrazi roztworami symicy epoksydowej Epidian 5. Praca magisterska wykonana w Katedrze Technologii i Technik Malarskich Wydziału Sztuk Pięknych UMK w Toruniu pod kierunkiem doc. dr. W. Domasłowskiego, s. 10 [mps przechowywany w bibliotece ZKMiRP, $\mathrm{nr}$ 47]; J. Ciabach, Wtaściwości symic sztucznych stosowanych w konserwacii zabytków, Torun 1997, s. 44; M. Czajnik, Środki i metody konserwacii zabytkowego drewna budowlanego, „Ochrona Zabytków”, nr 1, 1968, s. 26; W. Domasłowski, Konserwacja..., s. 55; idem, Wtasności ṡywic sætucznych oraz, ich zastosowanie do prac konserwatorskich, „Materiały Zachodnio-Pomorskie”, t. 6, 1960, s. 599; A. Lisewska, Konserwacja rzeźby drewnianej polichromowanej, praca magisterska, Toruń 1962, s. 48 [mps przechowywany w bibliotece ZKMiRP, nr 23]; W. Ślesiński, Konserwacja zabytkón squtuki, t. 2, s. 22; idem, Konserwacja zabytkón sztuki, t. 3, s. 21.

${ }_{17}$ Spis dokumentacii konserwatorskich zabytkón ruchomych, cz. 1: dla zabytków znajdujących się poza muzeami, O-Ż, s. 97. 
liny ${ }^{18}$. Najpóźniejszą znaną mi informację dotyczącą użycia tego impregnatu zawiera artykuł S. Matuschka-Greiffenclau ${ }^{19}$.

Jedyną zaleta przypisywana temu impregnatowi było powodowanie tylko nieznacznego zabarwienia drewna. Wprowadzenie roztworu kleju glutynowego wiązało się z jednoczesnym wchłonięciem przez drewno bardzo dużych ilości wody, co skutkowało jego silnym pęcznieniem. Sam klej natomiast jest kruchy, silnie higroskopijny, ma duży skurcz przy wysychaniu oraz jest podatny na atak mikroorganizmów. Wymienione wady eliminuja go jako impregnat ${ }^{20}$.

\section{Oleje schnące}

Oleje schnące to estry gliceryny i nienasyconych kwasów: linolowego, linolenowego i oleinowego oraz kwasów nasyconych: palmitynowego, stearynowego i innych. Należą do nich oleje: lniany, makowy, orzechowy, konopny i chiński ${ }^{21}$.

Najbardziej wartościowy spomiędzy europejskich olejów schnących jest olej lniany. Czysty oraz polimeryzowany w temperaturze $250-350^{\circ} \mathrm{C}$ przy użyciu związków niektórych metali - ołowiu, magnezu i kobaltu jako katalizatorów, był często stosowany do przesycania drewna ${ }^{22}$. W. Śle-

18 Ibidem, s. 141.

19 S. Matuschka-Greiffenclau, Zur Restaurierung des spätgotischen Altares aus Wehrda, "Denkmalpflege in Hessen", nr 1, 1989, s. 22-23. Abstrakt artykułu zamieszczony na http:// www.bcin.ca (dostęp 2005.01.05) wśród wykonywanych zabiegów wymienia ,impregnation with warm glue and wax".

${ }^{20}$ U. Bieszczad, op. cit., s. 9; B. Chaber, op. cit., s. 9; W. Kurpik, Ekstrakcia impregnatu z. reźáby polichromowanej (praca magisterska), Katedra Technologii i Technik Malarskich Studium Zabytkoznawstwa i Konserwatorstwa przy Wydziale Sztuk Pięknych UMK, Toruń 1962, s. 27 [mps przechowywany w bibliotece ZKMiRP, nr 24]; U. Schiessl, op. cit., s. 100; B. Slánský, op. cit., s. 185; W. Ślesiński, Konserwacja zabytkón sætuki, t. 1, s. 23; idem, Konserwacja zabytków sżtuki, t. 2, s. 20; K. Wieczorek, Krajowe środki do ochrony i konserwacii drewna w zabytkeach, Warszawa 1992, s. 133-136; M. Wierucka, op. cit., s. 29.

21 J. Hopliński, Farby i spoiwa malarskie, Wrocław 1990, s. 29.

22 Do celów malarskich i konserwatorskich najlepsze sa gatunki oleju lnianego tłoczone na zimno. Olej ma wówczas jasnożółtą barwę, jest bardziej ciekły niż gatunki tłoczone na gorąco, zawiera minimalną ilość substancji stałych. Twardnienie oleju - jego wysychanie 
siński podaje, że do XVIII wieku do impregnacji podobrazi drewnianych stosowano farbę olejną lub werniks olejny, natomiast w latach 1800-1918 poza werniksem olejnym stosowano również pokost $z$ minią ołowianą ${ }^{23}$. Pokost z glejtą ołowianą zalecany był także jako sposób utrwalania rzeźb drewnianych, niepełniących roli konstrukcyjnej, podczas przeprowadzonej w XIX wieku konserwacji Ołtarza Mariackiego ${ }^{24}$. Autor ten stwierdza też, że na początku XX wieku nastapiło ponowne zainteresowanie stosowaniem olejów schnących do impregnacji drewna. Myśl tę rozwijają A. Schönemann, M. Eisbein, A. Unger, M. Dell'mour, M. Frenzel i E. Kenndler w odniesieniu do terenu Niemiec, a w szczególności Saksonii. Tam popularność impregnacji olejem lnianym, również na gorąco, wzrosła po roku 1904. Czasami dla uzyskania właściwości biobójczych impregnatu do oleju dodawano fenolany. Później, celem obniżenia lepkości i zwiększenia penetracji, jako rozcieńczalnika używano olejku terpentynowego. Składnikami mieszaniny były też niekiedy olejek kamforowy i werniks bursztynowy, wyparty z czasem przez kalafonię. Po I wojnie światowej pojawiło się zainteresowanie olejem tungowym ${ }^{25} \mathrm{~W}$. Ślesiński przywołuje znacznie późniejszy przykład - receptę E. Willemsena z 1962 roku, w której jednym z podstawowych składników jest olej tungowy (tak zwany olej drzewny

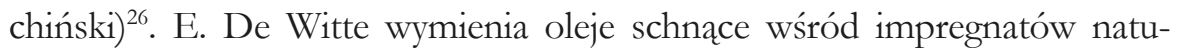
ralnych, po które sięgano do lat 30. ubiegłego stulecia ${ }^{27}$. M. Paciorek zalicza olej lniany do grupy preparatów, które były stosowane na początku

odbywa się w wyniku polimeryzacji oksydacyjnej. Właściwości błonotwórcze oleju lnianego polepsza się poprzez gotowanie lub przez nasycanie go w trakcie gotowania tlenem. Informacje te podaję za: J. Hopliński, op. cit., s. 31, 38; M. Kiepuszewska, M. Roznerska,

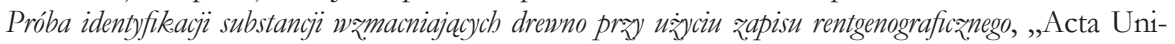
versitatis Nicolai Copernici Zabytkoznawstwo i Konserwatorstwo", XX, 1993, s. 153-154; U. Schiessl, op. cit., s. 100.

23 W. Ślesiński, Dawne metody i środki chemične stosowane prayy konserwacji malarstwa sz̨talugowego, „Ochrona Zabytków”, nr 1, 1984, s. 26.

${ }_{24}$ W. Ślesiński, Konserwacja Ottarza Mariackiego w XIX wieku w śmietle zachowanego ręeopisu, „Ochrona Zabytków”, nr 2, 1967, s. 9.

25 A. Schönemann, M. Eisbein, A. Unger, M. Dell'mour, W. Frenzel, E. Kenndler, Historic Consolidants for Wooden Works of Art in Saxony. An investigation by GC-MS and FTIR analysis, "Studies in Conservation", nr 2, 2008, s. 120.

26 W. Ślesiński, Konserwacja zabytkón sæutuki, t. 2, s. 21.

27 E. De Witte, op. cit., s. 1-1. 
$\mathrm{XX}$ wieku ${ }^{28}$. J. Krawczyk wymienia oleje schnące obok klejów zwierzęcych, wosku pszczelego i żywic naturalnych jako jeden ze stosowanych w przeszłości tradycyjnych impregnatów do wzmacniania elementów drewnianych meblii ${ }^{29}$. Zaskakujące stwierdzenie można znaleźć w pozycji I. Swaczyny, według której oleje schnące, a w szczególności olej lniany „spełniają wymagania stawiane impregnatom wzmacniającym strukturę zniszczonego drewna" ${ }^{30}$. U. Bieszczad pisze natomiast, że olej lniany, pokost oraz mieszaniny z żywicami nie były często używane do impregnacji drewna ${ }^{31}$. J. Ważny, omawiając preparaty wykorzystywane w przeszłości do tego celu, wymienia także oleje roślinne, stwierdzając, że między innymi ich stosowanie przyniosło pozytywne rezultaty w zakresie stabilizacji wymiarowej, szczególnie mniejszych obiektów, bez jednoczesnej poprawy właściwości technicznych tkanki drzewnej ${ }^{32}$.

Dzisiejszy stan wiedzy, doświadczenia zebrane przez lata i ocena stanu obiektów niegdyś wzmacnianych olejem każą stwierdzić, że impregnacja olejami schnącymi lub mieszaninami olejów i żywic nie wzmacnia dostatecznie osłabionej tkanki drzewnej, a produkty polimeryzacji oleju lnianego są szkodliwe dla drewna, gdyż utleniaja celulozę do oksycelulozy, intensyfikują jego destrukcję, powodując pękanie i brązowienie ${ }^{33}$. Ponadto, ze względu na ograniczony dostęp tlenu, w głębszych warstwach drewna wprowadzone do niego oleje roślinne przez lata pozostaja ciekłe ${ }^{34}$.

28 M. Paciorek, Badania..., s. 8.

29 J. Krawczyk, op. cit., s. 39.

30 I. Swaczyna, op. cit., s. 66.

31 U. Bieszczad, op. cit., s. 10; A. Schönemann, M. Eisbein, A. Unger, M. Dell'mour, W. Frenzel, E. Kenndler, op. cit., s. 118, 126.

32 J. Ważny, Stan i perspektywy konserwacii drewna zabytkowego, „Ochrona Zabytków”, nr 2, 1991, s. 81.

33 J. Bursze, Podtoża drewniane w malarstwie sz̨talugonym, Warszawa 1974, s. 22; M. Kiepuszewska, M. Roznerska, op. cit., s. 153-154; R. Munnikendam, op. cit., s. 71; U. Schiessl, op. cit., s. 100.

34 A. Schönemann, M. Eisbein, A. Unger, M. Dell'mour, W. Frenzel, E. Kenndler, op. cit., s. 123. 


\section{Roztwory żywic naturalnych}

Kalafonia $^{35}$, kolejny składnik spotykany w tej grupie impregnatów, to żywica małocząsteczkowa, tworzy roztwory o małej lepkości i dobrej penetracji ${ }^{36}$. Stosowana była rozpuszczona w etanolu lub w terpentynie. W. Ślesiński wskazuje, że „roztwór kalafoniowo-terpentynowy nieco zatłuszczał drewno", a alkoholowy cechowała zbyt wysoka lotność. Jako dodatków do roztworu kalafonii używano zazwyczaj szelaku, damary lub wosku ${ }^{37}$, choć zdarzały się i bardziej zaskakujące, np. zastosowane jednocześnie Vinoflex i wosk $^{38}$. Próbowano też impregnować kalafonia, wykorzystując nagrzewanie promiennikami podczerwieni ${ }^{39}$.

35 Kalafonia jest żywicą miękka, kruchą, o szklistym połysku i barwie od jasnożółtej do ciemnobrązowej. Otrzymywana jest z balsamu drzew iglastych drogą destylacji. Jej gęstość wynosi $1,071-1,083 \mathrm{~g} / \mathrm{cm}^{3}$, temperatura topnienia zawiera się w przedziale $110-150^{\circ} \mathrm{C}$, a współczynnik załamania światła równa się 1,525. W swym składzie zawiera kwasy żywiczne, między innymi pinarowy, sapinowy i kwas przechodzący w kwas sylwinowy, które w czasie podgrzewania przechodza w kwasy kalafoniowe: abietynowy i izopimarowy. Rozpuszcza się w acetonie, alkoholach: amylowym, butylowym, etylowym, metylowym, benzynie, czterochlorku węgla, eterze etylowym, ksylenie, toluenie i w olejku terpentynowym. Żywica ta jest mało odporna na działanie promieni ultrafioletowych; na skutek krystalizacji traci swe zdolności wiążące. Podwójne wiązanie występujące w łańcuchu kwasu abietynowego, stanowiącego 80\% składu kalafonii, jest przyczyną jej twardnienia i brunatnienia. Za: M. Doerner, Materialy w malarstwie $i$ ich zastosowanie, Warszawa 1975, s. 93; J. Hopliński, op. cit., s. 51; S. Jędrzejewska, P. Rudniewski, A. Wawrzeńczak, Substancje sælkodliwe dla zdrowia stosowane pray konserwacji dziet sqtuki, Warszawa 1974, s. 143; J. Lehmann, Chemia malarstwa i jego konserwacji, Biblioteka Muzealnictwa i Ochrony Zabytków, seria B, t. 37, 1974, s. 70; M. Kiepuszewska, M. Roznerska, op. cit., s. 153; B. Slánský, Technika malarstwa, t. 1: Materialy do malarstwa i konserwacji, Warszawa 1960, s. 80-82, 87.

36 U. Bieszczad, op. cit., s. 9; M. Czajnik, Konserwacja drewna środkami chemicznymi, [w:] Muzea skansenowskie w Polsce, Poznań 1979, s. 250; idem, Konserwacja drewna zabytkowego w polskich parkach etnograficznych, [w:] Ogólnopolska Konferencja Muzeón i Parków Etnograficznych, Opole 22 - 24 IX 1970 rok, Opole 1971, s. 131; idem, Środki..., s. 24; W. Domasłowski, Konserwacja..., s. 53; R. Munnikendam, op. cit., s. 71; U. Schiessl, op. cit., s. 100.

37 W. Ślesiński, Konserwacja zabytkón sz̨uki, t. 2, s. 20.

38 Spis dokumentacji konserwatorskich zabytków ruchomych, cz. 1: dla zabytków znajdujących się poza muzeami, A-N, s. 241.

39 Ibidem, s. 286. 
Impregnaty kalafoniowe były szeroko stosowane w konserwacji zabytkowego drewna polichromowanego ${ }^{40}$, jeszcze w latach 90., z czym trudno się zgodzić, polecała je I. Swaczyna ${ }^{41}$. Metodę kalafoniową stosowano także w konserwacji drewna archeologicznego ${ }^{42}$.

Impregnat ten ma jednak szereg istotnych wad, zasadniczo eliminujacych go z grupy środków obecnie stosowanych do drewna zabytkowego. Roztwory kalafonii barwią drewno, żywicę cechuje duża kwasowość, mała odporność na działanie czynników atmosferycznych oraz szybkie starzenie się. Z upływem czasu, zwłaszcza w środowisku o zwiększonej wilgotności, traci na skutek krystalizacji zdolności wiążące. Roztwory alkoholowe powodują ponadto pęcznienie drewna ${ }^{43}$.

40 M. Paciorek, Badania..., s. 8; U. Schiessl, op. cit., s. 100; Por. także: opis impregnacji roztworem kalafonii renesansowej figurki Mestwina z tryptyku znajdującego się w kościele w Żukowie koło Kartuz, [w:] J. Borowski, Ochrona zabytków, Poznań-Gdańsk 1954, s. 49, a także Spis dokumentacji konserwatorskich zabytków ruchomych, cz. 1: dla zabytków znajdujących się poza muzeami, A-N, s. 28, 38, 41, 62, 63-64, 77, 92-93, 108, 110, 111, 113, 118, 126-128, 142, 161-162, 194, 266, 267, 268 oraz Spis dokumentacij konserwatorskich zabytkón ruchomych, cz. 1: dla zabytków znajdujących się poza muzeami, O-Ż, s. 13, 21-23, 26, 44, 55, 61, 74, 105, 128, 144, 163, 179, 219, 231, 233, 235; J. Ważny, op. cit., s. 81. W swoich badaniach nad impregnacją drewna kalafonię wykorzystywali również E. Simunkova i J. Josef, por.: E. Simunkova, J. Josef, Petrifikace dreva v závislosti na polarite pouzitych rozpustedel, „Pamatky a priroda”, nr 5, 1988, s. 283-285 oraz eadem, Petrifikace dreva v qávislosti na polarite pouritych roapustedel 2. Oddnost proti zmenám vlbkosti a mechanicka pevnost, „Pamatky a priroda", nr 1, 1989, s. 27-29. Podaję na podstawie informacji zamieszczonych na http:// www.bcin.ca (dostęp 2005.01.05).

${ }^{41}$ I. Swaczyna, op. cit., s. 66, 67.

42 A. Kanwiszer, Konserwacja mokrego drewna, Zagadnienia konserwacji drewna, Biblioteka Muzealnictwa i Ochrony Zabytków, ser. B, t. 3, 1961, s. 61.

43 U. Bieszczad, op. cit., s. 9; J. Bursze, op. cit., s. 122; B. Chaber, op. cit., s. 9; M. Czajnik, Konserwacja drewna środkami..., s. 250; idem, Konserwacja drewna zabytkowego..., s. 131; idem, Środki..., s. 24-25; K. Dąbrowska, Konserwacja polichromii gotyckiej rzę́́by drewnianej na podstawie prepprowadzonej konserwacji figury Matki Boskiej Bolesnej ze Stupcy. Praca magisterska, Toruń 1955, s. 91 [mps przechowywany w bibliotece ZKMiRP, nr 7]; W. Domasłowski, Konserwacja..., s. 53; A. Dworakowska, Konserwacja i ewentualna rekonstrukecja polichromii rzeźby drewnianej (praca magisterska), Zakład Technologii i Technik Malarskich Studium Konserwatorstwa i Muzealnictwa przy Wydziale Sztuk Pięknych Uniwersytetu Mikołaja Kopernika w Toruniu 1955 r., s. 29-30 [mps przechowywany w bibliotece ZKMiRP, nr 9]; M. Kiepuszewska, M. Roznerska, op. cit., s. 153; E. Małachowicz, Konserwacja i rewaloryzacja architektury w zespołach i krajobrąie, Wrocław 1994, s. 282; W. Ślesiński, Konserwacja zabytków sžtuki, t. 1, s. 23; idem, Konserwacja zabytkón squtuki, t. 2, s. 20. 
Kolejną stosowaną w zabiegach nasycania żywicą była damara. Jej roztwory sporządza się droga bezpośredniego rozpuszczenia żywicy w olejku terpentynowym lub w benzynie, toluenie albo ksylenie. W konserwacji znalazły one zastosowanie jako werniksy i jako impregnaty do drewna ${ }^{44}$. Ich istotną wadą jest niska stabilność termiczna i fotochemiczna. Bardzo łatwo utleniają się przy udziale ciepła i światła, zwłaszcza jego części nadfioletowej $^{45}$. W wyniku tego procesu ${ }^{46}$ werniksy damarowe żółkna, tracą połysk

44 Damara jest żywicą miękką, wyciekającą w postaci balsamu z drzew z rodzaju Dipterocarpaceae. Spotykane są różne jej gatunki, najlepszym jest damara batawska. Damara ma gęstość 1,007-1,036 g/ $\mathrm{cm}^{3}$, a współczynnik załamania światła 1,515. Głównym składnikiem żywic damarowych są trój- i czterocykliczne terpeny, ponadto niewielkie ilości sekwiterpenów oraz oligomerycznej substancji o masie cząsteczkowej od 1800 do 4.000 j.m.a. Z frakcji trójterpenów wyodrębniono alkohole, ketony i kwasy karboksylowe. Topliwość jej jest różna, w zależności od pochodzenia, w temperaturze $65^{\circ} \mathrm{C}$ mięknie, a przy $100-150^{\circ} \mathrm{C}$ staje się ciekła. Damara batawska rozpuszcza się całkowicie w benzynie, chloroformie, czterochlorku węgla, kwasie octowym bezwodnym, olejku terpentynowym, częściowo w acetonie, alkoholu amylowym, etylowym, metylowym i w octanie amylu. W gorącym alkoholu rozpuszcza się całkowicie.Informacje powyższe podaję za: J. Ciabach, Badania dotycz̨ce starzenia i stabilizacii wspótczesnych werniksów malarskich, Toruń 1994, s. 70; idem, Damara na cenzurowanym, „Biuletyn Informacyjny Konserwatorów Dzieł Sztuki”, nr 3, 4, 1992, s. 15-16; M. Doerner, op. cit., s. 92; J. Hopliński, op. cit., s. 52-53; S. Jędrzejewska, P. Rudniewski, A. Wawrzeńczak, op. cit., s. 142; J. Lehmann, op. cit., s. 71; J. S. Mills, R. White, The Organic Chemistry of Museum Objects, Butterworths-London-Boston-Durban-Singapore-Sydney-Toronto-Wellington 1987, s. 93; B. Slánský, Technika malarstwa, t. 1, s. 80, 83-84, 87 oraz przykłady wykorzystania w pracach konserwatorskich zamieszczone w: Spis dokumentacji konserwatorskich zabytków ruchomych, cz. 1: dla zabytków znajdujących się poza muzeami, A-N, s. 109, 117, 170, 226; Spis dokumentacii konserwatorskich zabytków ruchomych, cz. 1: dla zabytków znajdujących się poza muzeami, O-Ż, s. 116.

45 J. Ciabach, Badania..., s. 71; idem, Damara..., s. 15; idem, Stabilizowany werniks damarowy, „Biuletyn Informacyjny Konserwatorów Dzieł Sztuki”, nr 1-4, 1994, s. 27; J. Jakubiak, M. Nowakowska, Porównanie własności Paraloidu B-72 i Paraloidu B-82, „Biuletyn Informacyjny Konserwatorów Dzieł Sztuki”, nr 3-4, 1996, s. 31; M. Wierucka, op. cit., s. 30.

$46 \mathrm{~J}$. Ciabach proces ten opisuje następującym, czterostopniowym schematem: „w wyniku utleniania powstają liczne związki z grupa karbonylowa; związki te ulegaja kondensacji aldolowej, katalizowanej przez tworzące się w trakcie utleniania kwasy karboksylowe;

powstające w wyniku kondensacji $\beta$-hydroksyketony lub $\beta$-hydroksyaldehydy ulegają dehydratacji i tworzą $\alpha, \beta$ - nienasycone aldehydy lub ketony;

seria takich reakcji prowadzi do związków z dużą liczbą wiązań nienasyconych, z których w wyniku izomeryzacji powstają układy chromoforowe, absorbujące w bliskim nadfiolecie i zakresie widzialnym; absorpcję zwiększają liczne grupy kar- 
i przeźroczystość, stają się bardziej kruche, a także tracą rozpuszczalność w rozpuszczalnikach o niskiej polarności ${ }^{47}$.

Stosowanie roztworów damary jako impregnatu do drewna nie było powszechne, choć literatura przedmiotu odnotowuje takie przykłady ${ }^{48}$ bądź tylko wymienia roztwory damary w grupie środków impregnacyjnych $^{49}$. Niekiedy żywicy tej używano w połączeniu z kalafoniąa ${ }^{50}$. M. Czajnik i W. Domasłowski podają wysoką cenę żywicy jako czynnik ograniczający jej użycie ${ }^{51}$. W. Ślesiński zwraca jednak uwagę na dobre wnikanie w drewno roztworu damary w benzynie lakowej ${ }^{52}$. J. Bursze i B. Chaber wskazuja z kolei na jej kruchośćs ${ }^{33}$.

Kolejno wśród żywic naturalnych, stosowanych w roztworach impregnacyjnych, wymienić należy mastyks. Rozpuszcza się on w alkoholach amylowym i butylowym, w ksylenie, toluenie, częściowo jest rozpuszczalny w acetonie, alkoholach etylowym i metylowym, czterochlorku węgla, dwusiarczku węgla i w olejku terpentynowym. Mastyks spośród żywic miękkich był i nadal jest najbardziej ceniony w technikach malarstwa artystyczne-

bonylowe i karboksylowe położone w sąsiedztwie sprzężonych ze sobą wiązań nienasyconych".

Cytuję za: J. Ciabach, Badania..., s. 71; idem, Damara..., s. 15.

${ }^{47}$ J. Ciabach, Badania..., s. 72; idem, Damara..., s. 15; J. Jakubiak, M. Nowakowska, op. cit., s. 31; M. Wierucka, op. cit., s. 30.

48 I. Haberland, Dokumentacja naukowa konserwacii obrazu Madonna z. Diieciatkiem na podobraziu drewnianym z. kościoła paraf. w Rajsku, pow. kaliskim. Praca magisterska, Toruń 1954, s. 40 [mps przechowywany w bibliotece ZKMiRP, nr 6]; Spis dokumentaci konserwatorskich zabytkón ruchomych, cz. 1: dla zabytków znajdujących się poza muzeami, A-N, s. 170; Spis dokumentacji konserwatorskich zabytków ruchomych, cz. 1: dla zabytków znajdujących się poza muzeami, O-Ż, s. 115-116.

49 U. Bieszczad, op. cit., s. 9; J. Bursze, op. cit., s. 22; B. Chaber, op. cit., s. 9; M. Czajnik, Konserwacja drewna zabytkowego..., s. 131; idem, Środki..., s. 25; W. Domasłowski, Konserwacja..., s. 53; S. Jędrzejewska, P Rudniewski, A. Wawrzeńczak, op. cit., s. 142; R. Munnikendam, op. cit., s. 71; B. Slánský, Technika malarstwa, t. 2, s. 185; W. Ślesiński, Konserwacja zabytków squtuki, t. 1, s. 23; E. De Witte, op. cit., s. 1-1.

50 Spis dokumentacji konserwatorskich zabytków ruchomych, cz. 1: dla zabytków znajdujących się poza muzeami, A-N, s. 109, 117, 266.

51 M. Czajnik, Konserwacja drewna zabytkowego..., s. 131; idem, Środki..., s. 25; W. Domasłowski, Konserwacja..., s. 53.

52 W. Ślesiński, Konserwacja zabytkón sz̨uki, t. 1, s. 23.

53 J. Bursze, op. cit., s. 22; B. Chaber, op. cit., s. 9. 
go $^{54}$. Wzmianki o możliwości stosowania roztworów żywicy mastyksowej do impregnacji drewna są w literaturze przedmiotu sporadyczne ${ }^{55}$.

$\mathrm{Na}$ uwagę, jako przynależny do tej grupy składników impregnatów, zasługuje również szelak. Oczyszczony, czyli pozbawiony wosku i innych zanieczyszczeń, rozpuszcza się w alkoholach: etylowym, metylowym, amylowym, butylowym i dwuacetonowym. W acetonie rozpuszcza się w 50-80\%, w chloroformie w $24-40 \%$, w olejku terpentynowym w $8-15 \%$. Nie rozpuszcza się w octanie etylu i toluenie ${ }^{56}$.

Roztwory szelaku w alkoholu etylowym były stosowane do impregnacji wzmacniającej drewna. W literaturze przedmiotu wymienia się tę żywicę wśród innych impregnatów ${ }^{57}$, jak też podaje opisy konkretnych prac konserwatorskich, w których została użyta ${ }^{58}$. Do impregnacji drewna me-

54 M. Doerner, op. cit., s. 91; J. Hopliński, op. cit., s. 51-52; J. Lehmann, op. cit., s. 71; J. S. Mills, R. White, op. cit., s. 93-95; B. Slánský, Technika malarstwa, t. 1, s. 80, 83, 87. Autorzy ci podają również podstawowe informacje na temat mastyksu. Jest to mianowicie żywica miękka, pozyskiwana z balsamu drzewa Pistacia Lentiscus. Najlepszy gatunek mastyksu pochodzi z wyspy Chios. Gęstość mastyksu wynosi 1,040-1,070 g/ $\mathrm{cm}^{3}$, temperatura topnienia $95-120^{\circ} \mathrm{C}$, a współczynnik załamania światła 1,536. Zawiera około $42 \%$ kwasów mestycynowych i około $50 \%$ żywicy beta (mestycyn i inne) oraz około $5 \%$ ciał gorzkich i $2 \%$ olejku lotnego. Wraz z upływem czasu żółknie, nabierając pomarańczowej barwy, staje się kruchy i mętnieje pod wpływem wilgoci.

55 U. Bieszczad, op. cit., s. 9; J. Bursze, op. cit., s. 22; J. Hopliński, op. cit., s. 52; R. Munnikendam, op. cit., s. 71; E. De Witte, op. cit., s. 1-1.

56 Adhesives..., s. 115; M. Doerner, op. cit., s. 93-94; J. Hopliński, op. cit., s. 61; S. Jędrzejewska, P. Rudniewski, A. Wawrzeńczak, op. cit., s. 144; J. Lehmann, Chemia..., s. 72; J. S. Mills, R. White, op. cit., s. 101-103; B. Slánský, Technika malarstwa, t. 1, s. 85-87. Tam też podstawowe informacje na temat żywicy.

Szelak jest żywicą średnio twarda, będącą produktem owada Coccus lacca, żyjącego w liściach figi Ficus religiosa w Indiach Wschodnich. Zawiera około 6\% wosku, 75\% żywicy, ponadto około 6,5\% barwnika, 9,5\% ciał obcych i 3,5\% wody. Temperatura topnienia szelaku wynosi $80-120^{\circ} \mathrm{C}$, a współczynnik załamania światła 1,516.

${ }^{57}$ U. Bieszczad, op. cit., s. 9; B. Chaber, op. cit., s. 9; J. Hopliński, op. cit., s. 62; S. Jędrzejewska, P. Rudniewski, A. Wawrzeńczak, op. cit., s. 144; J. Lehmann, Chemia..., s. 72; R. Munnikendam, op. cit., s. 71; M. Paciorek, Badania..., s. 8; U. Schiessl, op. cit., s. 100; mgr Marta Żurowska wymienia szelak jako jeden z impregnatów stosowanych w pracowni PKZ w Krakowie, wypowiedź zamieszczona w: T. Rudkowski, Sesja naukowa na temat konserwacii drewna polichromowanego, „Ochrona Zabytków”, nr 1, 1974, s. 78.

58 Spis dokumentacji konserwatorskich zabytków ruchomych, cz. 1: dla zabytków znajdujących się poza muzeami, A-N, s. 31, 34, 38, 48, 68, 73, 77, 82, 120, 148, 151, 166, 179, 194, 240, 256, 268, 269, 272, 276, 279, 287 oraz Spis dokumentaci konserwatorskich zabytków ruchomych, 
bli zabytkowych stosowana była mieszanina szelaku, glikolu etylenowego i alkoholu metylowego ${ }^{59}$. Rekomendację do stosowania tej żywicy zawiera pozycja I. Swaczyny ${ }^{60}$. Inni autorzy, podkreślając łatwość stosowania tego impregnatu, wskazywali również na jego wady. Roztwory szelaku nie gwarantowały równomiernej i głębokiej penetracji, barwiły drewno, a ponadto używane rozpuszczalniki - najczęściej alkohol etylowy, niekiedy metylowy, powodowały pęcznienie zarówno drewna, jak i polichromii. Trzeba też pamiętać, że szelak jest żywicą kruchą, względnie szybko ulegającą starzeniu, w wyniku czego na skutek procesów sieciowania stopniowo traci rozpuszczalnośćc1

\section{Wosk i masy woskowo-żywiczne}

Szczególnie istotne miejsce wśród impregnatów na bazie składników naturalnych zajmował wosk ${ }^{62}$ i masy woskowo-żywiczne. Najczęściej do impregnacji wzmacniającej drewna stosowany był wosk w mieszaninie $\mathrm{z}$ żywicami naturalnymi: kalafonią, damara, ewentualnie mastyksem w ilości od 30 do

cz. 1: dla zabytków znajdujących się poza muzeami, O-Ż, s. 9, 13, 16, 28, 29, 34, 43, 44, 54, 57, 62, 74, 80, 84, 86, 89, 93, 105, 106, 109, 112, 127, 128, 140, 163, 200, 210, 211, 222; M. Szeremeta, Konserwacja poliptyku ₹. Ksiqzinic Wielkich (1487-1491), Konserwacja malarstwa sztalugowego, Biblioteka Muzealnictwa i Ochrony Zabytków, ser. B, t. 27, 1970, s. 65 .

59 A. M. Wilmering, Traditions and trends in furniture conservation, "Reviews in Conservation", nr 5, 2004, s. 30.

${ }^{60}$ I. Swaczyna, op. cit., s. 66-67.

${ }^{61}$ J. Bursze, op. cit., s. 21-22; B. Chaber, op. cit., s. 9; W. Kurpik, Przemieszczania spoin w czasie wysychania mas trocinowych, [w:] Zabytkowe drewno konserwacja i badania, Warszawa 1987, s. 117; B. Slánský, Technika malarstwa, t. 2, s. 183; W. Ślesiński, Konserwacja zabytków squtuki, t. 1, s. 22-23; idem, Konserwacja zabytkón sz̨tuki, t. 2, s. 20.

${ }^{62}$ Woski są estrami wyższych alkoholi jednowodorotlenowych i wyższych kwasów tłuszczowych. Wosk pszczeli jest ciałem bezpostaciowym barwy szarożółtej. Topi się w temperaturze $63-65^{\circ} \mathrm{C}$, tężeje w temperaturze $60-61^{\circ} \mathrm{C}$. Rozpuszcza się zupełnie w chloroformie, dwusiarczku węgla, olejku terpentynowym i w olejach schnących (na ciepło). W eterze rozpuszcza się w $50 \%$, w benzynie w około $20 \%$, a w alkoholu na zimno nie rozpuszcza się. Por.: J. Hopliński, op. cit., s. 40-41; M. Kiepuszewska, M. Roznerska, op. cit., s. 152; J. S. Mills, R. White, op. cit., s. 41-42; B. Slánský, Technika malarstwa, t. 1, s. 92-93. 
$50 \%{ }^{63} \mathrm{z}$ dodatkiem terpentyny weneckiej ${ }^{64}$. W. Ślesiński cytuje ponadto recepturę, według której jednym ze składników jest balsam kopaiwa ${ }^{65}$, a J. Lehmann podaje, że do impregnacji obiektów etnograficznych stosowano mieszaninę wosku, parafiny i kalafonii ${ }^{66}$.

Zawartość żywicy wpływała na wzrost lepkości mieszaniny impregnacyjnej i tym samym na spadek zdolności penetracji w głąb drewna. Żywice decydowały też o właściwościach mechanicznych impregnatu. Wosk nadawał elastyczność, a dodatek terpentyny weneckiej miał ułatwiać penetrację ${ }^{67}$.

Mieszaniny woskowo-żywiczne przechodzą w podwyższonych temperaturach ze stanu stałego w ciekły. Po oziębieniu powracają do stanu pierwotnego, wypełniając wolne przestrzenie w drewnie. Wprowadzanie masy

63 B. Chaber, op. cit., s. 7; W. Domasłowski, Konserwacja..., s. 46; W. Domasłowski, K. Powidzki, Badania nad zastosowaniem roztworón ṡywic epoksydowych do impregnacji (wzmacniania) drewna, „Zeszyty Naukowe Uniwersytetu Mikołaja Kopernika w Toruniu”, III, 1968, s. 193; A, Grajkowska, Wosk w praktyce konserwatorskiej. Malarstwo sztalugowe na podobraziu tekstylnym $i$ drewnianym, malarstwo ścienne $i$ drewniana rę̧̧́ba polichromowana. Praca magisterska pod kierunkiem prof. dr Marii Roznerskiej, Zakład Konserwacji Malarstwa i Rzeźby Polichromowanej, Instytut Zabytkoznawstwa i Konserwatorstwa, Uniwersytet Mikołaja Kopernika, Toruń 2000, s. 58 [mps przechowywany w bibliotece ZKMiRP, nr 206]; M. Kiepuszewska, M. Roznerska, op. cit., s. 150; J. Lehmann, Konserwacja drewnianych zabytków etnograficznych $i$ archeologicznych. Badania $i$ prace nad metodyka, „Ochrona Zabytków”, nr 1, 1962, s. 26; S. M. Nakhla, A comparative study of resins for the consolidation of wooden objects, „Studies in Conservation”, nr 1, 1986, s. 38; M. Niedzielska, Badania technologične i konserwacja podobrazia drewnianego epitafum Wierzbiety z. Branic, „Ochrona Zabytków”, nr 2, 1970, s. 95; T. Rudkowski, op. cit., s. 78 - wypowiedź mgr Marty Żurowskiej (PKZ Kraków); W. Ślesiński, Konserwacja zabytkón sqtuki, t. 1, s. 23; idem, Konserwacja zabytków sztuki, t. 2, s. 21; idem, Konserwacja zabytków sætuki, t. 3, s. 21; M. Wójcik-Orkiszowa, Problemy konserwatorskie mystępujace pray obrazie „Optakiwanie” (ok. 1440) ₹. Muzeum Ziemi Żywieckiej, Konserwacja malarstwa sztalugowego, Biblioteka Muzealnictwa i Ochrony Zabytków, ser. B, t. 27, 1970, s. 78.

${ }^{64}$ W. Ślesiński, Konserwacja zabytków sæ̨uki, t. 1, s. 23; idem, Konserwacja zabytków sұtuki, t. 2, s. 21; idem, Konserwacja zabytków sztuki, t. 3, s. 21; M. Wójcik-Orkiszowa, op. cit., s. 78.

${ }^{65}$ W. Ślesiński, Konserwacja zabytkón sz̨uki, t. 1, s. 23.

${ }^{66}$ J. Lehmann, Konserwacja..., s. 26.

${ }_{67}$ W. Domasłowski, Konserwacja..., s. 46; W. Domasłowski, K. Powidzki, op. cit., s. 193-194; A. Grajkowska, op. cit., s. 58; M. Kiepuszewska, M. Roznerska, op. cit., s. 150; K. A. Krzyżyński, Badania nad stabilizacja podobrazia drewnianego. Praca magisterska napisana przy Katedrze Technologii i Technik Malarskich Wydziału Sztuk Pięknych w Toruniu pod kierunkiem doc. Jerzego Wolskiego, Torun 1968 r., s. 26 [mps przechowywany w bibliotece ZKMiRP, nr 41]; W. Ślesiński, Konserwacja zabytków sæ̨tuki, t. 2, s. 21; idem, Konserwacja zabytków štuki, t. 3, s. 21. 
do obiektu następowało na gorąco, poprzez pokrywanie roztopioną mieszanina, a następnie wtapianie żelazkiem, kauterami, promiennikami podczerwieni $^{68}$ lub przez zanurzenie obiektu $\mathrm{w}$ pojemniku z roztopioną masa ${ }^{69}$. Po wykonaniu zabiegu nadmiar masy usuwano mechanicznie przy użyciu ostrego narzędzia, następnie doczyszczano benzyną lakową ${ }^{70}$.

Roztopione masy woskowo-żywiczne mają dobra przenikliwość, wypełniały więc wolne przestrzenie $\mathrm{w}$ drewnie, przez co uzyskiwało ono nieco większą wytrzymałość mechaniczna. Jednak stosowane w trakcie zabiegu wysokie temperatury mogły spowodować zmiany i zniszczenia w obiektach polichromowanych. Impregnat ten cechuje brak skurczu przy zastyganiu, a dzięki wyeliminowaniu rozpuszczalnika nie powodował on pęcznienia drewna. Wodoodporność masy miała zapewnić ochronę drewna przed wilgocią i ograniczyć jego pracę powodowaną zmianami wilgotności powietrza. Wskazuje się jednak również na liczne wady tego impregnatu. Niewielka wytrzymałość mechaniczna wprowadzonych składników nie zapewnia dostatecznego wzmocnienia drewna, szczególnie w przypadku bardzo zniszczonych obiektów. Wosk wykazuje też tendencję do migracji ku powierzchni. Mieszaniny woskowo-żywiczne nie są także odporne na działanie niskich temperatur. Sam wosk już w temperaturze $-14^{\circ} \mathrm{C}$ traci swe właściwości wiążące. Istotną wadą jest wysoki współczynnik załamania światła, będący przyczyną ściemnienia zarówno nasyconego drewna, jak też polichromii i złoceń. Mieszaniny woskowo-żywiczne w dużym stopniu zwiększaja ciężar drewna ${ }^{71}$. W przypadku konieczności ponownej konserwacji

${ }^{68}$ J. Bursze, op. cit., s. 22; B. Chaber, op. cit., s. 7; W. Domasłowski, Konserwacja..., s. 46; idem, Zagadnienie..., s. 400; A. Grajkowska, op. cit., s. 58; M. Kiepuszewska, M. Roznerska, op. cit., s. 150; B. Slánský, Technika malarstwa, t. 2, s. 184; W. Ślesiński, Konserwacja zabytkón sztuki, t. 1, s. 23; idem, Konserwacja zabytków sztuki, t. 2, s. 21; idem, Konserwacja zabytkón sztuki, t. 3, s. 21.

${ }_{69}$ W. Domasłowski, Konserwacja..., s. 46; idem, Zagadnienie..., s. 400; M. Kiepuszewska, M. Roznerska, op. cit., s. 150; J. Lehmann, Konserwacja..., s. 26-27; H. J. Plenderleith, A. E. A. Werner, The Conservation of Antiquities and Works of Art. Treatment, Repair and Restoration, London 1957, s. 127-129.

${ }^{70}$ A. Grajkowska, op. cit., s. 58.

${ }^{71}$ Adhesives..., s. 127; U. Bieszczad, op. cit., s. 10; B. Chaber, op. cit., s. 7-8; W. Domasłowski, Konserwacja..., s. 46; W. Domasłowski, K. Powidzki, op. cit., s. 193-194; W. Domasłowski, Zagadnienie..., s. 400; A. Grajkowska, op. cit., s. 60-62; M. Kiepuszewska, M. Roznerska, op. cit., s. 152-153; W. Kurpik, Ekstrakcja..., s. 27; M. Makowska, op. cit., 
wcześniejsze zastosowanie impregnacji woskowej zdecydowanie ogranicza możliwość użycia innego materiału utwardzającego ${ }^{72}$, a w przypadku pęknięcia lub złamania klejenie przesyconego woskiem drewna jest bardzo utrudnione $\mathrm{e}^{73}$.

Zastosowanie mas woskowo-żywicznych do impregnacji drewna polichromowanego ma długą tradycję, sięgająca zdaniem W. Ślesińskiego początków XX wieku ${ }^{74}$. B. Slánský natomiast przeprowadzony przez siebie w roku 1931 zabieg impregnacji drewnianego podobrazia obrazu Siedzqca Madonna zwana Jindruchadecka opisywał jako nowatorski ${ }^{75}$. E. De Witte zaś wymienia wosk pszczeli wśród środków stosowanych w latach 30. i wcześniej ${ }^{76}$. Informacje o stosowaniu tego impregnatu, zarówno w Polsce, jak i za granica, sa w literaturze bardzo liczne. Czasem sa to tylko wzmianki ${ }^{77}$, czasem opisy sto-

s. 39; R. Munnikendam, op. cit., s. 71; H. J. Plenderleith, A. E. A. Werner, op. cit., s. 129; A. Schönemann, M. Eisbein, A. Unger, M. Dell'mour, W. Frenzel, E. Kenndler, op. cit., s. 119; K. Sibul, op. cit., s. 3; B. Slánský, op. cit., s. 183; W. Ślesiński, Konserwacja zabytkón sztuki, t. 1, s. 23; idem, Konserwacja zabytkón sztuki, t. 1, s. 21; idem, Konserwacja zabytków sətuki, t. 1, s. 21; M. Wierucka, op. cit., s. 30; J. Wziątek, Portret Filipa Melanchtona - konserwacja $i$ zagadnienia autorstwa. Praca magisterska wykonana w Katedrze Technologii i Technik Malarskich UMK, Torun 1967, s. 54 [mps przechowywany w bibliotece ZKMiRP, nr 33].

72 C. V. Horie, op. cit., s. 88; Por. także: wypowiedź mgr Marty Żurowskiej dotycząca konserwacji obrazu „Opłakiwanie” z Muzeum Ziemi Żywieckiej, [w:] T. Rudkowski, op. cit., s. 78; M. Wójcik-Orkiszowa, op. cit., s. 78.

73 J. Bursze, op. cit., s. 22; R. Munnikendam, op. cit., s. 71.

74 W. Ślesiński, Konserwacja zabytków sz̨tuki, t. 2, s. 21.

75 B. Slánský, Technika malarstwa, t. 2, s. 183-185.

76 E. De Witte, op. cit., s. 1-1.

77 J. Bursze, op. cit., s. 22, W. Domasłowski, Zagadnienie..., s. 400; J. Flik, Spostrzęzenia technologiczno-konserwatorskie w zwiazku ₹ uystawami organizowanymi w Muzeum Okeregonym w Toruniu ₹. okazji 500-lecia urodzin Mikołaja Kopernika, „Rocznik Muzeum w Toruniu”, t. 6, 1977, s. 178; C. V. Horie, op. cit., s. 88; J. Krawczyk, op. cit., s. 39; W. Kurpik, Przemieszczanie..., s. 117; S. Matuschka-Greiffenclau, op. cit., s. 22-23. Podaję na podstawie informacji zamieszczonych na http://www.bcin.ca (dostęp 2005.01.05); M. Paciorek, Badania..., s. 8; E. Packard, Conservation of decayed wood sculpture, [w:] Preprints of the Contributions to the New York Conference on Conservation of Stone and Wooden Objects, 7-13 June 1970, vol. 2: Conservation of Wooden Objects, London 1970, s. 13-22. Podaję na podstawie informacji zamieszczonych na http://www.bcin.ca (dostęp 2005.01.07); H. J. Plenderleith, A. E. A. Werner, op. cit., s. 128; E. Šzimůnková, polimeryzacja monomerów w drewnie, [w:] Chemia w konserwacji zabytków. Materialy z. II Ogólnopolskiego Zjazdu Chemików-Konserwatorów, Toruń-Bachotek wrzesień 1981, Warszawa 1982, s. 199; N. Szunke, Z problematyki konserwacii zabytków ruchomych w Holandii, „Ochrona Zabytków”, nr 1, 1965, s. 45. 
sowanych metod lub prac przeprowadzonych przy konkretnych obiektach ${ }^{78}$. Pojawiaja się też głosy krytyki w stosunku do niewłaściwie wykonanych zabiegów i ich negatywnych skutków obserwowanych w zabytkach ${ }^{79}$.

\section{Wnioski}

Przedstawione powyżej - dzisiaj już w zasadzie niestosowane - impregnaty oparte na naturalnych klejach, olejach, żywicach i woskach w wielu przypadkach stały się już nierozłącznym, choć wtórnym składnikiem zabytków. Wraz z upływającym czasem coraz częstsza staje się konieczność rekonserwacji obiektów poddanych pracom kilkadziesiąt lat wcześniej. Wydaje się więc, że świadomość różnorodności stosowanych przez naszych poprzedników materiałów, ich właściwości, zmian, jakim ulegają w wyniku procesów starzenia oraz wynikających z nich skutków, możliwych do zaobserwowania w obiektach zabytkowych, jest nieodzowna.

78 B. H. Beardsley, A flexible balsa back for the stabilization of a Botticelli panel painting, [w:] Conservation of Wood in Painting and the Decorative Arts, Preprints of the Contributions to the $O x$ ford Congress, 17-23 September 1978, London 1978, s. 153; M. Hamsik, The flattering and stabilization of soft wood panel by means of the method which respects their original technical structure, [w:] Conservation of Wood in Painting and the Decorative Arts, Preprints of the Contributions to the Oxford Congress, 17-23 September 1978, London 1978, s. 175-176; B. Jessel, G. Price, Some methods of repair and conservation of easel paintings on wooden supports, [w:] Conservation of Wood in Painting and the Decorative Arts, Preprints of the Contributions to the Oxford Congress, 17-23 September 1978, London 1978, s. 173; J. Lehmann, Konserwacja..., s. 26-27; M. Niedzielska, op. cit., s. 89-96; streszczenie referatu mgr Danuty Mitraszewskiej i mgr Wandy Zaufal (PKZ Warszawa) oraz wypowiedź mgr Żurowskiej (PKZ Kraków), [w:] T. Rudkowski, op. cit., s. 77, 78; Spis dokumentacii konserwatorskich zabytków ruchomych, cz. 1: dla zabytków znajdujących się poza muzeami, A-N, s. 43, 58, 93, 94, 109, 111, 114, 117, 118, 124, 184, 211, 250, 276, 282 oraz Spis dokumentaci konserwatorskich zabytkón ruchomych, cz. 1: dla zabytków znajdujących się poza muzeami, O-Ż, s. 8, 20, 27, 28, 63, 89, 92, 97, 115, 118, 205, 237; S. Stawicki, Przenoszenie na nowe podtoże za pomoca kleju epoksydowego malowidet na drewnie ₹. çéściowo pozostawionym podobraziem impregnowanym mieszanina woskowa, "Ochrona Zabytków", nr 2, 1967, s. 47, 50; M. Wójcik-Orkiszowa, op. cit., s. 77-78.

${ }^{79}$ G. Kostecki, M. Paciorek, Wspótczesne konstrukcje stabilizujace podtoża oraz. metody strukturalnego wzmacniania drewna w konserwacji obrazón tabliconych, [w:] Studia i Materialy Wydziału Konserwacji i Restauracii Dziet Sztuki Akademii Sztuk Pieknych w Krakowie, t. 6: Krakowska sžota konserwacii w programie TEMPUS, Kraków 1996, s. 84. 


\section{Summary}

Historically used consolidants

for strengthening impregnation treatment of damaged, polychrome, antique wood

- preliminary survey.

Part I: Materials based on natural constituents

This paper deals with the number of materials, based on natural constituents, used for strengthening impregnation treatment of antique, wooden art objects till about early seventies of $20^{\text {th }}$ century. To this group belong animal glues, vegetable drying oils, colophony, dammar, mastic and shellac solutions as well as waxes, especially beeswax, sometimes used with an addition of resins.

The reader is introduced with their properties, lying stress on drawbacks, negative aspects and harmful effects of their applications to wood, polychromy and gilding. 